\section{Nitrogen and Carbon Mineralization Dynamics of Manures and Composts}

\author{
T.K. Hartz, J.P. Mitchell, and C. Giannini \\ Department of Vegetable Crops, University of California, Davis, CA 95616
}

Additional index words. soil fertility, organic practices

\begin{abstract}
Nitrogen and carbon mineralization rates of 19 manure and compost samples were determined in 1996, with an additional 12 samples evaluated in 1997. These organic amendments were mixed with a soil : sand blend at $2 \%$ by dry weight and the amended blends were incubated at constant moisture for $12(1996)$ or 24 weeks $(1997)$ at $25{ }^{\circ} \mathrm{C}$. Net $\mathrm{N}$ mineralization was measured at 4- (1996) or 8-week (1997) intervals, $\mathrm{C}$ mineralization at 4-week intervals in 1997. Pots of the amended blends were also seeded with fescue (Festuca arundinacea Shreb.) and watered, but not fertilized, for 17 (1996) or 18 weeks (1997); $\mathbf{N}$ phytoavailability was estimated from fescue biomass $N$ and mineral $N$ in pot leachate. An average of $16 \%, 7 \%$, and $1 \%$ of organic $N$ was mineralized in 12 weeks of incubation in 1996, and an average of $15 \%, 6 \%$, and $2 \%$ in 24 weeks of incubation in 1997, in manure, manure compost, and plant residue compost, respectively. Overall, $\mathrm{N}$ recovery in the fescue assay averaged $11 \%, 6 \%$, and $2 \%$ of total amendment $\mathrm{N}$ for manure, manure compost, and plant residue compost, respectively. Mineralization of manure $\mathrm{C}$ averaged $35 \%$ of initial $\mathrm{C}$ content in 24 weeks, while compost $\mathrm{C}$ mineralization averaged only $14 \%$. Within 4 (compost) or 16 weeks (manure), the rate of mineralization of amendment $C$ had declined to a level similar to that of the soil organic $\mathrm{C}$.
\end{abstract}

The use of compost and manure as soil amendments, long a standard practice for organic farmers, is growing in popularity with conventional vegetable farmers in California and elsewhere. This increased usage is fueled in part by recognition that conventional cropping patterns and the intensive tillage typically employed in vegetable production have resulted in loss of soil organic matter. Another factor in many areas is the increased supply of compost because of legislatively mandated recycling of urban yard and landscape wastes (Warnert, 1996).

In order to obtain maximum economic value from these organic amendments, and to minimize $\mathrm{NO}_{3}-\mathrm{N}$ pollution potential, $\mathrm{N}$ management practices must be adjusted for expected $\mathrm{N}$ mineralization from the amendment. Many studies have evaluated $\mathrm{N}$ mineralization rates of various animal manures (Smith and Peterson, 1982). Bitzer and Sims (1988) reported that $\mathrm{N}$ mineralization from 20 poultry manures averaged $66 \%$ of organic $\mathrm{N}$ over a 140-d incubation, but rates varied widely among manures. Douglas and Magdoff (1991) found $\mathrm{N}$ mineralization from cow and horse manure much slower, varying from $\approx 15 \%$ of organic $\mathrm{N}$ to net $\mathrm{N}$ immobilization over a 67 d laboratory incubation. Chae and Tabatabai (1986) and Castellanos and Pratt (1981) showed that $\mathrm{N}$ mineralization rate varied widely among manures of various types. In a 140-d greenhouse study, Castellanos and Pratt reported rates varying from $57 \%$ of organic $\mathrm{N}$ for chicken manure, to only $17 \%$ for dairy manure. Chae and Tabatabai found similar results in a 26-

Received for publication 3 June 1999. Accepted for publication 20 Aug. 1999. The cost of publishing this paper was defrayed in part by the payment of page charges. Under postal regulations, this paper therefore must be hereby marked advertisement solely to indicate this fact. week laboratory incubation, with chicken manure mineralizing $53 \%$ compared to only $31 \%$ for horse manure.

Composting tends to reduce $\mathrm{N}$ mineralization rate of organic wastes (manures, crop residues, etc.), but reported mineralization rates
Table 1. Selected characteristics of the organic amendments. from compost vary nearly as widely as those for noncomposted manures. Castellanos and Pratt (1981) found rates ranging from $4 \%$ to $35 \%$ in a 10-month assay for manure composts, while Douglas and Magdoff (1991) reported that three manure composts had net $\mathrm{N}$ immobilization over a 67-d incubation. Buchanan and Gliessman (1991) found $\mathrm{N}$ recovery in a broccoli (Brassica oleracea L. Italica Group) crop to be as high as $57 \%$ of applied compost N. Murillo et al. (1995) and Iglesias-Jimenez and Alvarez (1993) reported $22 \%$ and $21 \% \mathrm{~N}$ mineralization from urban waste compost, respectively, over a 6-month period. However, Hartz et al. (1996) and Hartz and Giannini (1998) found short-term N immobilization to be common with urban green waste composts, and net mineralization of only $1 \%$ to $3 \%$ in a 4 -month assay.

The primary objective of this study was to determine the $\mathrm{N}$ mineralization dynamics of a range of manures and composts representative of those currently used as soil amendments in California vegetable production. Concurrent measurement of carbon mineralization provided insight on the effect of these amendments on soil microbial activity, and on soil organic matter maintenance.

\section{Materials and Methods}

Samples of 31 organic amendments intended for agricultural use were collected from various sources throughout central and southern California, 19 in 1996 and 12 in 1997

\begin{tabular}{|c|c|c|c|c|c|c|c|}
\hline $\begin{array}{l}\text { Amendment } \\
\text { no. }\end{array}$ & Description & Total N & Organic N & $\mathrm{P}$ & $\mathrm{K}$ & $\mathrm{C}$ & C/N Ratio \\
\hline \multicolumn{8}{|c|}{ 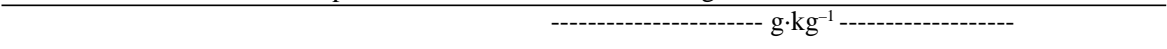 } \\
\hline & & 1996 & & & & & \\
\hline 1 & Pelletized poultry manure & 47 & 39 & 52 & 26 & 213 & 4.5 \\
\hline 2 & Aged poultry manure & 31 & 29 & 26 & 29 & 282 & 9.1 \\
\hline 3 & & 27 & 27 & 23 & 27 & 268 & 9.8 \\
\hline 4 & Aged feedlot manure & 20 & 20 & 13 & 14 & 250 & 12.4 \\
\hline 5 & Poultry manure compost & 38 & 36 & 23 & 29 & 217 & 5.7 \\
\hline 6 & & 27 & 27 & 14 & 30 & 249 & 9.1 \\
\hline 7 & & 24 & 23 & 29 & 28 & 210 & 8.8 \\
\hline 8 & & 20 & 19 & 16 & 5 & 162 & 8.0 \\
\hline 9 & & 20 & 19 & 18 & 6 & 158 & 7.8 \\
\hline 10 & & 13 & 13 & 20 & 17 & 136 & 10.2 \\
\hline 11 & Feedlot manure compost & 22 & 22 & 8 & 31 & 251 & 11.4 \\
\hline 12 & & 21 & 21 & 6 & 20 & 185 & 8.8 \\
\hline 13 & Crop residue compost & 12 & 12 & 2 & 14 & 111 & 9.3 \\
\hline 14 & Municipal yard waste compost & 16 & 16 & 3 & 9 & 236 & 14.4 \\
\hline 15 & & 14 & 14 & 3 & 9 & 191 & 13.3 \\
\hline 16 & & 16 & 16 & 3 & 11 & 208 & 13.0 \\
\hline 17 & & 16 & 16 & 2 & 9 & 221 & 13.8 \\
\hline 18 & & 13 & 13 & 2 & 6 & 200 & 15.4 \\
\hline 19 & & 10 & 10 & 3 & 14 & 120 & 12.0 \\
\hline & & 1997 & & & & & \\
\hline 20 & Dewatered poultry manure & 33 & 30 & 11 & 20 & 298 & 9.0 \\
\hline 21 & Aged poultry manure & 25 & 22 & 19 & 32 & 292 & 11.6 \\
\hline 22 & Aged feedlot manure & 24 & 20 & 11 & 17 & 302 & 12.5 \\
\hline 23 & Poultry manure compost & 26 & 24 & 14 & 21 & 181 & 7.0 \\
\hline 24 & Feedlot manure compost & 22 & 21 & 8 & 32 & 199 & 9.3 \\
\hline 25 & & 20 & 19 & 12 & 32 & 167 & 8.2 \\
\hline 26 & & 20 & 18 & 10 & 6 & 201 & 10.1 \\
\hline 27 & & 19 & 18 & 10 & 32 & 174 & 9.3 \\
\hline 28 & Dairy manure compost & 15 & 14 & 11 & 18 & 155 & 10.5 \\
\hline 29 & & 12 & 12 & 5 & 15 & 173 & 14.0 \\
\hline 30 & Municipal yard waste compost & 14 & 14 & 3 & 8 & 217 & 15.5 \\
\hline 31 & & 17 & 17 & 4 & 10 & 220 & 12.9 \\
\hline
\end{tabular}


(Table 1). Total $\mathrm{N}$ ranged from 10 to $47 \mathrm{~g} \cdot \mathrm{kg}^{-1}$, total carbon from 111 to $302 \mathrm{~g} \cdot \mathrm{kg}^{-1}$. Amendments 1 and 20 were fresh poultry manures dried and pelletized (\#1 only) by the poultry producer; other manure samples were more typical unprocessed materials, collected onfarm just prior to spreading on the soil. The composts represented a variety of blends of manure, crop residues, and urban yard and landscape wastes. They were either collected from finished windrows at the compost site, or on-farm just prior to spreading.

All samples were air-dried and screened through 12-mm mesh to remove coarse particles. Total $\mathrm{C}$ and $\mathrm{N}$ in each screened amendment were determined using a combustion gas analyzer(Carlo Erba 1500; Fisons Instruments, Beverly, Mass.). Each amendment was then mixed at $2 \%$ by dry weight with a blend of 1 coarse sand : 1 soil [Yolo silt loam (fine-silty, mixed, nonacid, thermic Typic Xerorthent)] from a field in a tomato (Lycopersicon esculentum Mill.)/wheat (Triticum aestivum L.) rotation near Davis. These amendment/soil/ sand blends were used in both an aerobic laboratory incubation and a lath house pot experiment to estimate $\mathrm{N}$ and $\mathrm{C}$ mineralization rates.

In the laboratory experiment, the amended and nonamended soil/sand blends were brought to equilibrium moisture content by a 3 -d exposure to $25-\mathrm{kPa}$ pressure, then incubated in sealed jars at $25^{\circ} \mathrm{C}$ for 12 (1996) or 24 weeks (1997). At either 4- (1996) or 8-week (1997) intervals, moist subsamples of the soil blends were extracted in $2 \mathrm{~N} \mathrm{KCl}$ and analyzed for $\mathrm{NH}_{4}-\mathrm{N}$ and $\mathrm{NO}_{3}-\mathrm{N}$ by the method of Carlson (1978). The change in mineral $\mathrm{N}$ concentration over the incubation period represented net $\mathrm{N}$ mineralization or immobilization. There were three (1996) or four (1997) replicate samples (jars) per soil blend. To determine whether the silt loam soil substantially influenced the mineralization rate of the amendments, two of the amendments (\#20 and 30) were blended with a mixture of 1 coarse sand : 1 loam soil [Camarillo loam (fine-loamy, mixed, calcareous, thermic Typic Xerorthents)] collected from a field in a vegetable crop rotation near Oxnard, Calif. These amended blends were included in the 1997 laboratory incubation study.

Carbon mineralization rate was measured in the 1997 study by monitoring the $\mathrm{CO}_{2}$ concentration in the headspace of the jars using an infrared gas analyzer. Measurements were made at 4-week intervals, with the jars purged with fresh air after measurement. Mineralization during the initial 3-d moisture equilibration period was estimated by moistening additional samples of the amended soil blends to the gravimetric water content of the pressure-equilibrated samples and measuring $\mathrm{CO}_{2}$ evolution after $3 \mathrm{~d}$ in sealed jars.

In the lath house study conducted at Davis, Calif., four 4-L pots of each soil blend were seeded with 'Bonsai' fescue (Festuca arundinacea Shreb.), arranged in a completely randomized design, and watered, but not fertilized, from 8 May to 4 Sept. 1996, or 15 July to 20 Nov. 1997. In both years the fescue was clipped and oven-dried three times during the

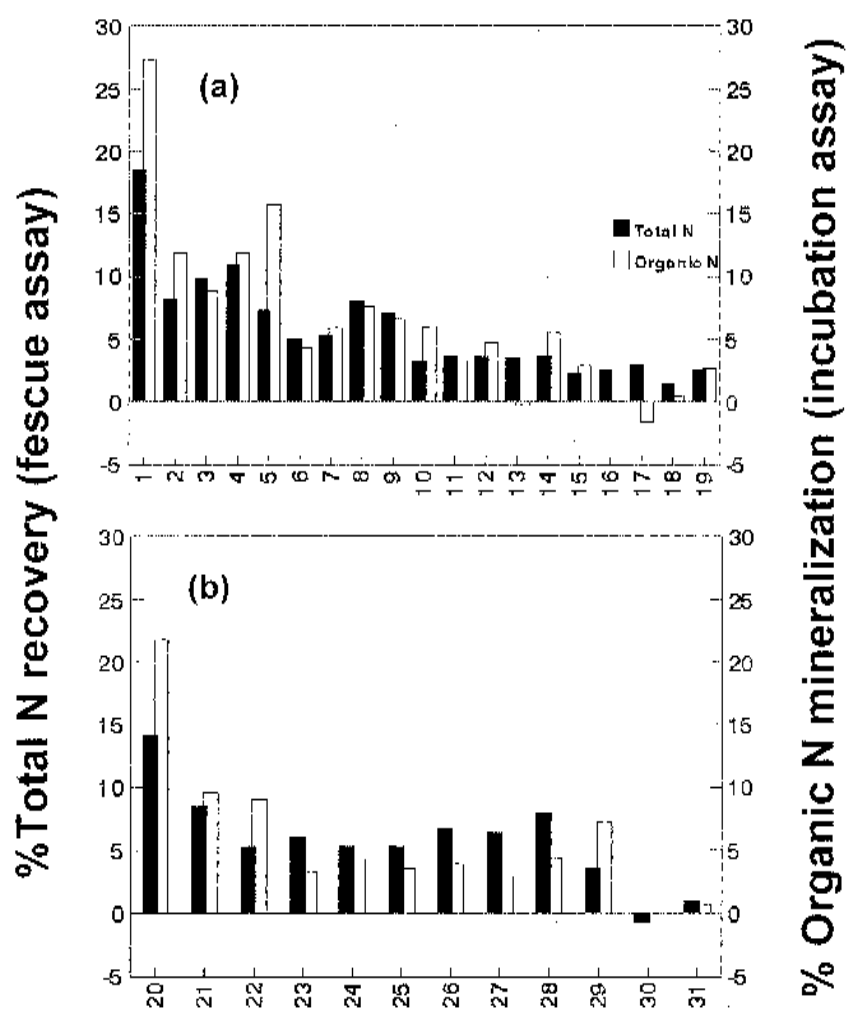

\section{Amendment}

Fig. 1. Percentage of total amendment N recovered in the (a) 17-week (1996) or (b) 18-week (1997) fescue assay, and percent organic N mineralized during (a) 12 weeks (1996) or (b) 16 weeks (1997) of aerobic incubation. Standard error averaged $0.9 \%$ for total $\mathrm{N}$ recovery, $1.1 \%$ for organic $\mathrm{N}$ mineralization.

Table 2. Correlation $(r)$ of initial amendment $\mathrm{C}$ and $\mathrm{N}$ content, $\mathrm{C}$ and $\mathrm{N}$ mineralization rate, and fescue growth.

\begin{tabular}{|c|c|c|c|c|c|}
\hline Factor & $\mathrm{FDW}^{\mathrm{z}}$ & TNRF & ONMF & ONMI & OCMI \\
\hline & & & 1996 & & \\
\hline Amendment total $\mathrm{N}^{\mathrm{y}}$ & $0.65^{* *}$ & $0.81^{* *}$ & 0.04 & $0.88^{* *}$ & $0.48^{*}$ \\
\hline Amendment organic $\mathrm{N}$ & $0.65^{* *}$ & $0.76^{* *}$ & 0.12 & $0.83^{* *}$ & $0.50^{*}$ \\
\hline Amendment $\mathrm{C}$ & 0.46 & 0.32 & $0.64^{* *}$ & 0.29 & $0.58^{* *}$ \\
\hline Amendment $\mathrm{C} / \mathrm{N}$ & $-0.51^{*}$ & $-0.66^{* *}$ & 0.33 & $-0.70^{* *}$ & -0.22 \\
\hline OCMI & $0.57^{* *}$ & $0.62^{* *}$ & $0.52^{*}$ & 0.52 & \\
\hline ONMI & $0.66^{* *}$ & $0.91^{* *}$ & 0.02 & & \\
\hline ONMF & $0.52^{*}$ & 0.16 & & & \\
\hline \multirow[t]{2}{*}{ TNRF } & $0.88^{* *}$ & & & & \\
\hline & & & 1997 & & \\
\hline Amendment total N & $0.83^{* *}$ & $0.74^{* *}$ & -0.01 & $0.73^{* *}$ & $0.59^{*}$ \\
\hline Amendment organic $\mathrm{N}$ & $0.82^{* *}$ & $0.72^{* *}$ & 0.12 & $0.70^{* *}$ & 0.52 \\
\hline Amendment $\mathrm{C}$ & 0.29 & $0.35^{* *}$ & -0.46 & $0.66^{*}$ & $0.79^{* *}$ \\
\hline Amendment $\mathrm{C} / \mathrm{N}$ & $-0.74^{* *}$ & $-0.60^{*}$ & -0.36 & -0.18 & 0.09 \\
\hline OCMI & 0.48 & $0.57^{*}$ & -0.30 & $0.85^{* *}$ & \\
\hline ONMI & $0.70^{* * *}$ & $0.82^{* *}$ & 0.07 & & \\
\hline ONMF & 0.20 & 0.24 & & & \\
\hline TNRF & $0.93^{* *}$ & & & & \\
\hline
\end{tabular}

${ }^{\mathrm{z}} \mathrm{FDW}=$ fescue dry weight; TNRF $=\%$ total nitrogen recovery in fescue assay; ONMF $=\%$ organic $\mathrm{N}$ mineralized in fescue assay; $\mathrm{ONMI}=\%$ organic $\mathrm{N}$ mineralized in incubation assay; $\mathrm{OCMI}=\%$ organic $\mathrm{C}$ mineralized in incubation assay.

${ }^{\mathrm{y}} \mathrm{g} \cdot \mathrm{kg}^{-1}$ total $\mathrm{N}$, organic $\mathrm{N}$, or $\mathrm{C}$ in amendment.

${ }^{*, * *}$ Significant at $P \leq 0.05$ or 0.01 , respectively.

experiment, followed by the harvest and drying of total fescue biomass (tops and roots) on the end date. Fescue $\mathrm{N}$ content was determined by the method of Sweeney (1989). Leachate from the pots was captured and analyzed for mineral Nby the method of Carlson (1978).Recovery of $\mathrm{N}$ from the amendments was calculated as total fescue $\mathrm{N}$ plus mineral $\mathrm{N}$ in leachate, minus those quantities from pots of nonamended soil blends.

\section{Results}

Percentage of amendment total $\mathrm{N}$ recovered in the fescue assay (TNRF) ranged from $19 \%$ for amendment 1 (pelletized poultry ma- 
nure) to slight immobilization in amendment 30 (urban waste compost) (Fig. 1). An average of $11 \%$ of total $\mathrm{N}$ was recovered from manures, $6 \%$ from composts containing manures, and $2 \%$ from composts made exclusively from crop residues or urban yard waste. Similar results were found in the laboratory incubation, in which $16 \%, 7 \%$, and $1 \%$ of organic $\mathrm{N}$ was mineralized in manure, manure compost, and plant residue compost, respectively in 1996. In 1997, manures mineralized $14 \%$ of organic $\mathrm{N}$ in 16 weeks (the measurement period closest to the length of the fescue assay), while manure composts averaged $4 \%$, and plant residue composts $<1 \%$.

Correlation of TNRF and percent organic $\mathrm{N}$ mineralized in the incubation (ONMI) was high in both years $(r=0.91$ and 0.82 in 1996 and 1997, respectively; Table 2). The strong correlation between fescue dry weight (FDW) and TNRF ( $r=0.88$ and 0.93 in 1996 and 1997, respectively) emphasized that fescue growth was restricted primarily by $\mathrm{N}$ availability, and that any growth response stimulated by other characteristics of the amendments was limited. Both TNRF and ONMI were positively correlated with amendment $\mathrm{N}$ content.

Percent organic $\mathrm{N}$ mineralized in the fescue assay (ONMF, calculated by adjusting percent $\mathrm{N}$ recovery for initial mineral $\mathrm{N}$ content of the amendments) was not correlated with either TNRF or ONMI. The initial mineral $\mathrm{N}$ concentration of a number of amendments (including most of the manures) was $>1.5 \mathrm{~g} \cdot \mathrm{kg}^{-1}$, which in some cases exceeded the total $\mathrm{N}$ recovered in the fescue biomass. Much of the initial mineral $\mathrm{N}$ was apparently lost to volatilization or denitrification, or incorporated into soil microbial biomass, before uptake by fescue or leaching from the pots. This resulted in extremely low estimates of organic $\mathrm{N}$ mineralization in numerous samples. Overall, ONMF averaged only $2 \%$ compared with $6 \%$ for both ONMI and TNRF.

The dynamics of $\mathrm{N}$ mineralization differed considerably among amendment types, and varied somewhat among samples of the same type (Fig. 2). The dried poultry manures (\#1 and 20) were by far the most active amendments, mineralizing $15 \%$ to $18 \%$ of organic $\mathrm{N}$ in the first 8 weeks. By contrast, manure \#3 immobilized $\mathrm{N}$ in the first 4 weeks, and no appreciable mineralization occurred until 8 to 12 weeks. Several manure composts showed initial immobilization (\#6 and 13), while \#5 (the compost with the highest $\mathrm{N}$ content) showed relatively rapid and sustained mineralization throughout the incubation period. Most plant residue composts showed initial N immobilization, with slow net mineralization thereafter. The nonamended Davis soil mix mineralized $1.5 \%$ of organic $\mathrm{N}$ in 12 weeks (1996) and $1.9 \%$ in 24 weeks (1997). The nonamended Oxnard soil mix mineralized $2.5 \%$ of organic $\mathrm{N}$ in 24 weeks.

The effect of the soil mix on amendment $\mathrm{N}$ mineralization was minimal. In 24 weeks of incubation, $18 \%$ of organic $\mathrm{N}$ was mineralized when amendment \#20 was blended with the Oxnard soil, compared with $20 \%$ in the Davis soil. Amendment \#30 showed 1\% net $\mathrm{N}$ im-

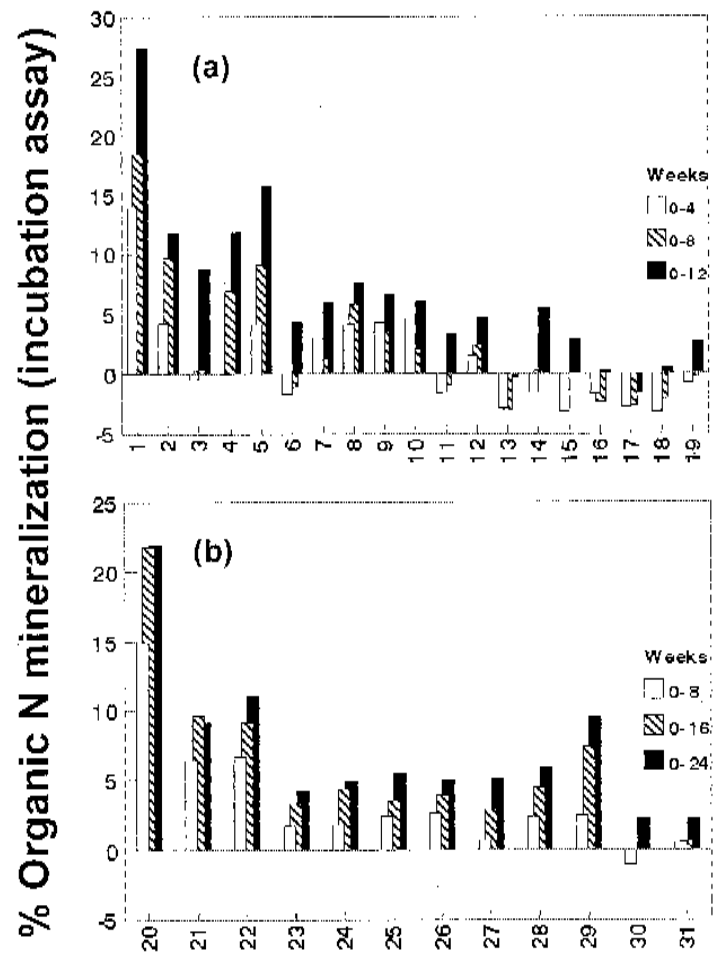

Amendment

Fig. 2. Rate of organic N mineralization during 12 or 24 weeks of aerobic incubation in (a) 1996 and (b) 1997 , respectively. Standard error averaged $1.1 \%$.

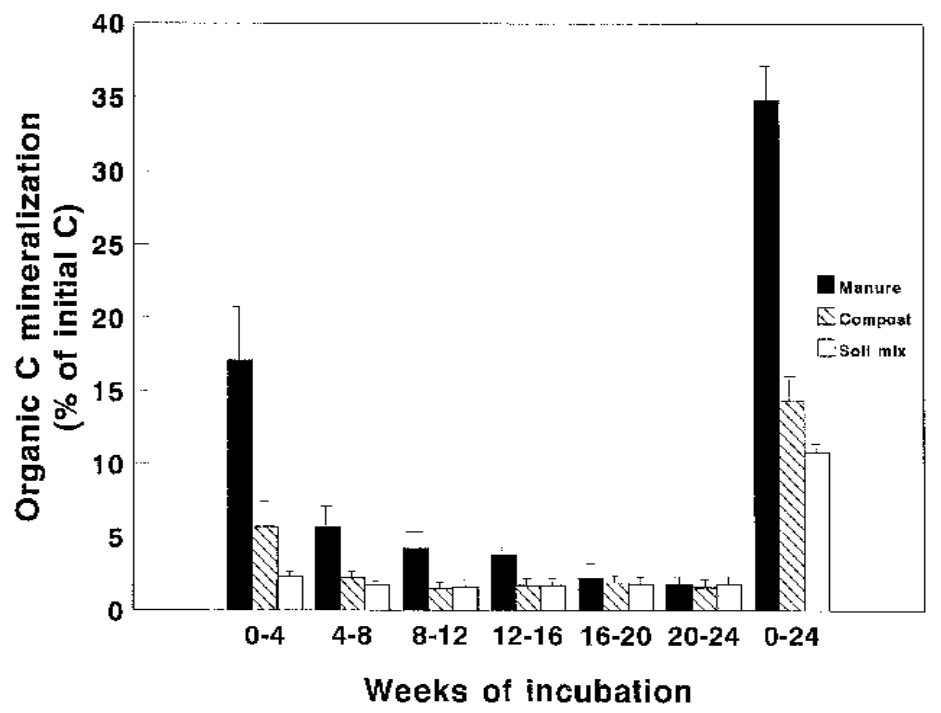

Fig. 3. Mean cumulative C mineralization by amendment type during 24 weeks of aerobic incubation in 1997 (amendments 20-31). Bars indicate standard error.

mobilization vs. $2 \% \mathrm{~N}$ mineralization in the Oxnard and Davis soil, respectively.

Manure had high initial rates of $\mathrm{C}$ mineralization, averaging $17 \%$ of initial $\mathrm{C}$ in the first 4 weeks of incubation (Fig. 3). Manure C mineralization rate declined over time, approaching the level of the nonamended soil mix within 16 weeks. Composts had substantially lower $\mathrm{C}$ mineralization rates than did manures, reflecting the loss of labile $\mathrm{C}$ during composting; initial $\mathrm{C}$ content averaged 272 and $189 \mathrm{~g} \cdot \mathrm{kg}^{-1}$ for manures and composts, respectively. Initial $\mathrm{C}$ mineralization rate of compost was substantially higher than that of the nonamended soil mix in the first 4 weeks ( $6 \%$ vs. $2 \%$ ), with rates similar to the nonamended mix thereafter. Manure composts and plant residue composts had similar $\mathrm{C}$ mineralization rates. Manures and composts mineralized an average of $35 \%$ and $14 \%$ of initial C, respectively, over 24 weeks of incubation.

\section{Discussion}

Nitrogen mineralization rate of manures and composts was relatively low, and within a 
narrow range for both groups of materials. Recovery of $\mathrm{N}$ in the fescue assay ranged from only $5 \%$ to $18 \%$ of total $\mathrm{N}$ for manures, and was $8 \%$ or less for all composts except \#5, which had the highest N content. Similar results were obtained in the incubation experiment. These results contrast with prior research, in which larger variations in mineralization rates were observed among manures, with generally higher rates. Bitzer and Sims (1988) reported N mineralization rates of poultry manure samples ranging from $21 \%$ to $\approx 100 \%$ in a 140 -d incubation. However, most of the 20 manures tested were of much higher $\mathrm{N}$ content (up to $8 \%$ of dry weight). We found $\mathrm{N}$ content was positively correlated with mineralization rate in 1996 and 1997. Chae and Tabatabai (1986) found mineralization rates of chicken and cow manure averaged $53 \%$ and $35 \%$, respectively, in five different soils over a 26-week incubation. Their samples were collected fresh and were incubated at $30^{\circ} \mathrm{C}$; in the present study, most manure samples came from stockpiled, aged material, and all were incubated at $25^{\circ} \mathrm{C}$. Castellanos and Pratt (1981) reported available $\mathrm{N}$ (initial total $\mathrm{N}$ - final organic $\mathrm{N}$ ) of manures ranging from $13 \%$ to $65 \%$ in a 10 -month incubation, but these rates would include any losses to volatilization or denitrification, and may have significantly overestimated plant-available $\mathrm{N}$.

The apparent loss of much of the initial mineral $\mathrm{N}$ in the amendments studied here occurred in previous studies as well. Bitzer and Sims (1988) reported that an average of $65 \%$ of initial mineral $\mathrm{N}$ of poultry manure was rapidly lost after soil incorporation, probably through ammonia volatilization. Hadas et al. (1983) found as much as $22 \%$ of soilapplied poultry manure total $\mathrm{N}$ was lost after soil application, mostly through volatilization.

The $\mathrm{N}$ mineralization rates of composts were more similar to those reported previously. Available N from four manure composts tested by Castellanos and Pratt (1981) averaged $17 \%$ over a 10 -month incubation. Douglas and Magdoff (1991) found slight net $\mathrm{N}$ immobilization from three manure composts over a 67-d incubation, while Hadas and Portnoy (1994) reported $\mathrm{N}$ mineralization rates of similar composts averaged $<10 \%$ in 32 weeks. Wen et al. (1995) reported apparent N mineralization of $\approx 10 \%$ from a manure compost over a field growing season, as measured by crop N recovery. Short-term Nimmobilization was common with urban yard waste composts, with slow net mineralization thereafter (Hartz et al., 1996; Hartz and Giannini, 1998).

Higher compost $\mathrm{N}$ mineralization rates have been reported. Working with urban waste compost, Murillo et al. (1995) found 22\% mineralization over 22 weeks of incubation, while Iglesias-Jimenez and Alvarez (1993) found $\approx 21 \%$ mineralization in a 6-month pot study. However, in both studies the authors emphasized that the composts were highly mature; furthermore, the compost used by IglesiasJimenez and Alvarez was $>3 \% \mathrm{~N}$, suggesting a feedstock other than typical urban green waste. The apparent recovery of as much as
$50 \%$ of applied compost $\mathrm{N}$ by a broccoli crop over a single growing season (Buchanan and Gliessman, 1991) was particularly unusual, given the relatively low $\mathrm{N}$ content of the com-

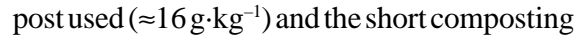
period employed (35-40 d).

Several studies have examined the ability of various laboratory analytical procedures to predict the $\mathrm{N}$ mineralization potential of organic amendments (Castellanos and Pratt, 1981; Chescheir et al, 1986; Douglas and Magdoff, 1991; Okeefe et al., 1986). However, given the relatively narrow range of $\mathrm{N}$ mineralization rates within categories of amendments observed in this study, a predictive test would probably have little practical value. Averaging the $\mathrm{N}$ recovery in the fescue assay and the $\mathrm{N}$ mineralization rate during incubation (12 weeks in 1996, 16 weeks in 1997) gave average estimates of plant available $\mathrm{N}$ of $20 \%, 9 \%, 6 \%$, and $2 \%$ for dried chicken manure, other manure, manure compost, and plant residue compost, respectively.

The low $\mathrm{N}$ mineralization rates measured suggested that very large amendment application rates would be required to significantly increase short-term soil $\mathrm{N}$ supply. This was particularly true of composts, and may help to explain the crop $\mathrm{N}$ deficiency frequently encountered in fields in transition to organic management. At typical amendment application rates, obtaining a substantial increase in soil N supply would require a long-term program of repeated application. The growth and incorporation of a legume cover crop has a much greater potential to enhance short-term soil N availability (Hu et al., 1997; Kuo et al., 1997b; Stivers and Shennan, 1991; Utomo et al, 1990).

The $\mathrm{C}$ mineralization rates measured in the incubation study demonstrated the value of manure and compost application in maintaining or enhancing soil organic C content. Within 16 weeks of incubation, $\mathrm{C}$ mineralization rate of all amendments had declined to about that of the nonamended soil mix. Mean C mineralization in the first 16 weeks of incubation was only $31 \%$ and $11 \%$ of initial C for manures and composts, respectively. Castellanos and Pratt (1981) reported similar rates for composts, but somewhat higher rates for manures; however, the manures they evaluated were of higher initial C content than those in the current study. Sikora and Yakovchenko (1996) found only $5 \%$ or $14 \% \mathrm{C}$ mineralization during $60 \mathrm{~d}$ of incubation from a municipal solid waste compost or biosolids compost, respectively. This contrasts with the much more rapid mineralization of $\mathrm{C}$ from common cover crops, which can exceed $50 \%$ of initial C content within 8 weeks after soil incorporation (Hu et al., 1997; Kuo et al., 1997a).

In summary, a range of manures and composts representative of those used as soil amendments in California vegetable production showed relatively modest rates of $\mathrm{N}$ and $\mathrm{C}$ mineralization, with narrow ranges in these parameters among similar samples. These results indicate the value of these amendments in long-term soil building, and their limitations in enhancing short-term $\mathrm{N}$ availability.

\section{Literature Cited}

Bitzer, C.C. and J.T. Sims. 1988. Estimating the availability of nitrogen in poultry manure through laboratory and field studies. J. Environ. Qual. 17:47-54.

Buchanan, M. and S.R. Gliessman. 1991. How compost fertilization affects soil nitrogen and crop yield. BioCycle 32(12):72-77.

Carlson, R.M. 1978. Automated separation and conductimetric determination of ammonia and dissolved carbon dioxide. Anal. Chem. 50:1528-1531.

Castellanos, J.Z. and P.F. Pratt. 1981. Mineralization of manure nitrogen-Correlation with laboratory indexes. Soil Sci. Soc. Amer. J. 45:354-357.

Chae, Y.M. and M.A. Tabatabai. 1986. Mineralization of nitrogen in soils amended with organic wastes. J. Environ. Qual. 15:193-198.

Chescheir, G.M., P.W. Westerman, and L.M. Safley. 1986. Laboratory methods for estimating available nitrogen in manures and sludge. Agr. Wastes 18:175-195.

Douglas, B.F. and F.R. Magdoff. 1991. An evaluation of nitrogen mineralization indices for organic residues. J. Environ. Qual. 20:368-372.

Hadas, A., B. Bar-Yosef, S. Davidov, and M. Sofer. 1983. Effect of pelleting, temperature and soil type on mineral nitrogen releases from poultry and dairy manures. Soil Sci. Soc. Amer. J. 47:1129-1133.

Hadas, A. and R. Portnoy. 1994. Nitrogen and carbon mineralization rates of composted manures incubated in soil. J. Environ. Qual. 23:1184-1189.

Hartz, T.K., F.J. Costa, and W.L. Schrader. 1996. Suitability of composted green waste for horticultural uses. HortScience 31:961-964.

Hartz, T.K. and C. Giannini. 1998. Duration of composting of yard wastes affects both physical and chemical characteristics of compost and plant growth. HortScience 33:1192-1196.

Hu, S., N.J. Grunwald, A.H.C. van Bruggen, G.R Gamble, L.E. Drinkwater, C. Shennan, and M.W. Demment. 1997. Short-term effects of cover crop incorporation on soil carbon pools and nitrogen availability. Soil Sci. Soc. Amer. J. 61:901-911.

Iglesias-Jimenez, E. and C.E. Alvarez. 1993. Apparent availability of nitrogen in composted municipal refuse. Biol. Fert. Soils 16:313-318.

Kuo, S., U.M. Sainju, and E.J. Jellum. 1997a. Winter cover crop effects on soil organic carbon and carbohydrate in soil. Soil Sci. Soc. Amer. J. 61:145-152.

Kuo, S., U.M. Sainju, and E.J. Jellum. 1997b. Winter cover cropping influence on nitrogen in soil. Soil Sci. Soc. Amer. J. 61:1392-1399.

Murillo, J.M., R. Lopez, F. Cabrera, and P. MartinOlmedo. 1995. Testing a low-quality urban compost as a fertilizer for arable farming. Land Use and Mgt. 11:127-131.

Okeefe, B.E., J. Axley, and J.J. Meisinger. 1986. Evaluation of nitrogen availability indexes for sludge compost amended soil. J. Environ. Qual. 15:121-128.

Sikora, L.J. and V. Yakovchenko. 1996. Soil organic matter mineralization after compost amendment. Soil Sci. Soc. Amer. J. 60:1401-1404.

Smith, J.H. and J.R. Peterson. 1982. Recycling of nitrogen through land application of agricultural, food processing, and municipal wastes, p. 791832. In F.J. Stevenson (ed.). Nitrogen in agricultural soils. Agron. Monogr. 22. ASA, Madison, Wis.

Stivers, L.J. and C. Shennan. 1991. Meeting the nitrogen needs of processing tomatoes through winter cover cropping. J. Prod. Agr. 4:330-335.

Sweeney, R.A. 1989. Generic combustion method for determination of crude protein in feeds: Collaborative study. J. Assn. Offic. Anal. Chem. 72:770-774.

Utomo, M., W.W. Frye, and R.L. Blevins. 1990. Sustaining soil nitrogen for corn using hairy vetch cover crop. Agron. J. 82:979-983.

Warnert, J. 1996. Agriculture could provide a major market for recycled green waste. California Agr. 50(5):8-10.

Wen, G., T.E. Bates, and R.P. Voroney. 1995. Evaluation of nitrogen availability in irradiated sewage sludge, sludge compost and manure compost. J. Environ. Qual. 24:527-534.

HortScience, Vol. 35(2), April 2000 